\title{
Synergistic anti-obesity effects of red cabbage and chromium administration on obese rats
}

\author{
Nawal. A. Tahoon \\ Assist. Prof. of Nutrition and Food Science, Department of Home Economic, \\ Faculty of Specific Education, Benha University, Egypt.
}

\begin{abstract}
This research was conducted to evaluate synergistic effects of red cabbage leaves either powder or methanolic extract with or without chromium on obese rats by evaluation nutritional indicators, serum lipids profiles, antioxidant enzymes, and some hepatic marker. After induction of obesity in rats by feed in high fat diet for six weeks, obese rats were randomly classified into six groups (seven rats in each) that include positive control group (basal diet), cabbage powder ( $15 \%$ of cabbage powder in basal diet) group, chromium (basal diet and $4.5 \mu \mathrm{g} / \mathrm{kg}$ body weight $/ \mathrm{d}$ chromium) group, cabbage extract (basal diet and 20 $\mathrm{mg} / \mathrm{kg}$ / body weight /d of cabbage extract ) group, cabbage powder + chromium ( $15 \%$ of cabbage powder in basal diet and $4.5 \mu \mathrm{g} / \mathrm{kg}$ body weight $/ \mathrm{d}$ chromium) group and cabbage extract + chromium (basal diet and $20 \mathrm{mg} / \mathrm{kg} / \mathrm{d}$ of cabbage extract and $4.5 \mu \mathrm{g} / \mathrm{kg} / \mathrm{d}$ chromium) group. The experiment period was 60 days after induction of obesity. The obtained results recorded that administration of cabbage powder with chromium or cabbage extract with chromium could lower body weight gain (BWG) and feed intake (FI) and elevate feed efficiency ratio (FER) compared to positive obese control group. All treated groups showed improvement in both serum and liver lipids profiles and liver function enzymes appeared prominently in cabbage powder with chromium and cabbage extract with chromium groups compared with positive control group. It is recommended to administer red cabbage leaves or its extract with chromium as a diet for patients with obesity
\end{abstract}

Key wards: red cabbage - chromium - obesity - rats- blood lipids antioxidants.

\section{INTRODUCTION}

Obesity is a dangerous health problem that results from an imbalance of energy intake and energy expenditure associated with abnormal excessive body fat and dramatic metabolic disorders such as non-alcoholic fatty liver disease, dyslipidemia, type 2 diabetes as well as coronary heart disease (Michalakis et al., 2013). Consumption of high-fat diet is related with inflammation, insulin resistance, oxidative stress, variations in liver chemistry and structure, and elevation risk of liver damage (Kim et al., 2010 and Lee et al., 2021). 
Weight reduction needs pharmaceutical interventions, caloric restriction and elevates physical activity. Surgery for severe obesity and anti-obesity drugs need more money and may have negative side effects (Fried et al., 2008 and Baetge et al., 2017).

Chromium is a trace element, essential for the maintenance of normal metabolism of lipids and carbohydrate. Some animals and clinical studies proved that chromium has a positive significant effect in reducing body weight (Pittler et al., 2003). Chromium is essential cofactor to enhance the effects of insulin on target tissues and inhibit increase in inflammatory markers and oxidative stress levels in cultured monocytes exposed to high glucose levels (Jain et al., 2007, Jain et al., 2010 and Chang et al., 2021).

Epidemiological and animal studies have shown that vegetable-rich diet is related with lower incidence of cancer, cardiovascular disease, and metabolic diseases so it is a cheap way to improve health and life (Navaro et al., 2017).

Red cabbage is belonging to Brassicaceae family, has more protective anthocyanin polyphenols phytonutrients that give the distinctive red color. Leaves of red cabbage also have antioxidant (vitamins), anti-inflammatory and other structurally diverse phytochemicals as glucosinolates and isothiocyanate precursors that prevent cancer. The hepatoprotective and neuroprotective effects of red cabbage are connected with high fiber, low calorie and rich source of anthocyanins (Podsę-dek et al., 2006 and Majkowska-Gadomska and Wierzbicka, 2008). Also, red cabbage has antioxidant capacity as it is rich in polyphenols, vitamins, minerals, anthocyanins and glucosinolates. Glucosinolates are transformed into isothiocyanates which lower inflammation. kaemferol and isorhamnetin in Brassica juncea L. leaves have antioxidant and protect against diabetes (Leja et al., 2010, Draghici et al., 2013 and Jana et al., 2017)

Therefore, this research was conducted to evaluate synergistic effects of red cabbage leaves either powder or methanolic extract alone or in combination with chromium on obese rats induced by high fat diet consumption.

\section{MATERIALS AND METHODS}

\section{Materials}

Forty two adult male white albino rats (Sprague Dawley Strain) weighing $120 \pm 10 \mathrm{~g}$, were obtained from Agricultural Research Center, Giza, Egypt. Red cabbage (Brassica oleracea L. var. capitata f. rubra DC.) was purchased from a local market in Banha. Chromium capsules drug produced by Arab company for pharmaceuticals and medicinal plants and purchased from 
pharmacy of Banha city. Each capsule contains $200 \mu \mathrm{g}$ of chromium piclonate equivelant to $24.85 \mu \mathrm{g}$ chromium. The human therapeutic dosage of the drug was $400 \mu \mathrm{g}$ daily. Chromium piclonate was dissolved in water to obtain the rat dose $(4.5 \mu \mathrm{g} / \mathrm{kg})$ according to previous research of Vincent (2006).

\section{Methods}

Cabbage leaves were washed in distilled water to remove any contaminants, cut into small pieces and dried at $45^{\circ} \mathrm{C}$ for 72 hours in hot oven, then grinded to powder. To obtain ethanolic leaf extracts, leaves of red cabbage were freeze-dried for three days, immersed in $80 \%(\mathrm{v} / \mathrm{v})$ ethanol at $70^{\circ} \mathrm{C}$ with stirring for four hours and filtered through Whatman filter paper then concentrated using a rotary evaporator. Ethanolic leaf extracts were stored at $4^{\circ} \mathrm{C}$ till use according to Zhang et al., (2018).

Basal diet was prepared according to Reeves et al., (1993). The high fat diet is basal diet contain $400 \mathrm{~g}$ beef tallow in substitution of $50 \mathrm{~g}$ corn oil $100 \mathrm{~g}$ sucrose and 250 starch. Rats were adapted for a week under standardized conditions for animal facilities. Rats were fed on high fat diet for six week in order to induce obesity till their weight reached $250 \pm 10 \mathrm{~g}$ (Im et al., 2018).

Obese rats were randomly classified into six groups (seven rats in each) as follows.

1- Positive control group fed on basal diet and did not receive any treatment.

2- Cabbage powder group fed on basal diet supplemented with $15 \%$ of cabbage powder

3- Chromium group fed on basal diet and administered $4.5 \mu \mathrm{g} / \mathrm{kg} / \mathrm{bw} / \mathrm{d}$ chromium by oral stomach tube.

4- Cabbage extract group fed on basal diet and $20 \mathrm{mg} / \mathrm{kg} / \mathrm{bw} / \mathrm{d}$ of cabbage extract by oral stomach tube.

5- Cabbage powder + chromium group fed on basal diet supplemented with $15 \%$ of cabbage powder and administered by $4.5 \mu \mathrm{g} / \mathrm{kg} / \mathrm{bw} / \mathrm{d}$ chromium by oral stomach tube

6- Cabbage extract + chromium group that fed on basal diet and $20 \mathrm{mg} / \mathrm{kg} /$ bw/d of cabbage extract and $4.5 \mu \mathrm{g} / \mathrm{kg} / \mathrm{bw} / \mathrm{d}$ chromium by oral stomach tube.

Food and water were provided ad libtium. Daily feed intake (FI) and weekly body weight gain (BWG) were maintained. Ethical guidelines were maintained during animal handling and permission. After 60 days, blood samples were obtained from orbital plexusby fine capillary tube then centrifuged at 3000rpm by centrifuge (Heraeus Sepetech,Germany). Liver from each rat were collected after sacrificing, washed with saline and kept in ice-cold buffered saline till analyses. 
Serum cholesterol (CHO), triglyceride (TG), high density lipoprotein (HDLc) and very low density lipoprotein (VLDLc) were estimated as described by Cohn et al., (1988), Foster and Dumns (1973), and Friedewald et al., (1972). Serum superoxide dismutase (SOD), catalase (CAT), glutathione transferase (GST), glutathione peroxidase (GPx) and malondialdehyde (MDA), were measured using the methods described by Nandi and Chatterjee (1988), Claiborne (1985), Ellman (1959), Necheles et al., (1970) and Uchiyama and Mihara (1978), respectively. Serum alanine\&aspartate amino transferase (ALT\& AST), alkaline phosphatase (ALP), gamma glutamyl transferase $(\gamma \mathrm{GT})$ and lactate dehydrogenase (LDH) enzyme activities were estimated using the kinetic methods of Tietz et al., (1976). Liver total lipids (TL), CHO and TG were measured as described by Folch et al., (1957), Wease et al., (1975) and Zlatkis and Zak (1969), respectively.

Feed efficiency ratio (FER), Low-density lipoprotein cholesterol (LDLC) and atherogenic index (CHO/HDLc) were calculated according to Friedewald et al., (1972) and Rosenfeld (1989), respectively.

\section{Statistical analyses:}

Results were presented as means \pm standard deviations (SD). Results were compared by one-way analysis of variance with Tukey post hoc analysis. Differences were significantly different at $P \leq 0.05$ according to Abo-Allam (2003).

\section{RESULTS AND DISSCUSION}

Table (1): Nutritional indicators of obese rats.

\begin{tabular}{|l|l|l|l|l|l|l|}
\hline $\begin{array}{c}\text { Groups } \\
\text { Variables }\end{array}$ & $\begin{array}{c}\text { Positive } \\
\text { control }\end{array}$ & $\begin{array}{c}\text { Cabbage } \\
\text { powder }\end{array}$ & $\begin{array}{c}\text { Cabbage } \\
\text { extract }\end{array}$ & chromium & $\begin{array}{c}\text { Cabbage } \\
\text { powder with } \\
\text { chromium }\end{array}$ & $\begin{array}{c}\text { Cabbage } \\
\text { extract with } \\
\text { chromium }\end{array}$ \\
\hline BWG (g) & $115.87 \pm$ & $90.55 \pm$ & $85.76 \pm$ & $95.77 \pm$ & $80.54 \pm$ & $67.70 \pm$ \\
& $7.56^{\mathrm{a}}$ & $4.11^{\mathrm{b}}$ & $4.11^{\mathrm{c}}$ & $5.33^{\mathrm{b}}$ & $3.27^{\mathrm{c}}$ & $3.99^{\mathrm{d}}$ \\
\hline FI (g) & $30.71 \pm$ & $24.35 \pm$ & $22.55 \pm$ & $24.96 \pm$ & $19.35 \pm$ & $17.38 \pm$ \\
& $3.14^{\mathrm{a}}$ & $2.30^{\mathrm{b}}$ & $2.11^{\mathrm{bc}}$ & $2.14^{\mathrm{b}}$ & $1.81^{\mathrm{c}}$ & $1.30^{\mathrm{C}}$ \\
\hline FER & $0.062 \pm$ & $0.061 \pm$ & $0.063 \pm$ & $0.063 \pm$ & $0.069 \pm$ & $0.065 \pm$ \\
& $0.002^{\text {cd }}$ & $0.003^{\mathrm{d}}$ & $0.001^{\mathrm{c}}$ & $0.005^{\mathrm{c}}$ & $0.004^{\mathrm{a}}$ & $0.007^{\mathrm{b}}$ \\
\hline
\end{tabular}

Results are expressed as Mean \pm SD

BWG: body weight gain, FI: feed intake, and FER: feed efficiency ratio

Mean values in each raw having different superscript were significantly different at $p \leq 0.05$

Table (1) showed the effect of red cabbage powder or extract in combination with or without chromium on body weight gain (BWG), feed intake (FI), and feed efficiency ratio (FER) of experimental rats after 60 days of treatment. 
There was a significant increase in the BWG and FI of positive control rat group when compared to other groups. The body weight gain was significantly lower in cabbage powder and chromium groups, then cabbage extract and cabbage powder with chromium groups, lastly the lowest value was in cabbage extract with chromium group compared to positive obese control group. The feed intake was significantly lower in the treatment groups compared to positive obese control group. The lowest values of food intake were observed in cabbage powder with chromium and cabbage extract with chromium groups. FER was not significantly changed in cabbage powder; chromium and cabbage extract groups while FER was significantly increased in cabbage powder with chromium and cabbage extract with chromium compared to positive obese control group after 60 days of treatment.

The decline of body weight gain and feed intake is related to composition of red cabbage as it has high dietary fiber content which helps prevent colon cancer, elevation of cholesterol, diabetes and obesity (Draghici et al., 2013). Quercetin and rutin are flavonoids in cabbage, could improve glucose tolerance and insulin resistance so reduce body weight in hyperlipidemic rats. Reduction of weight and fat mass without changes in lean body mass was observed in rutin and quercetin treatment (Henagan et al., 2015 and Jovanovski et al., 2020). Chromium picolinate is oral treatment for reduction of body weight by increase lean body mass and lower of body fat with increasing of basal metabolic rate (Pittler et al., 2003 and Molz et al., 2021).

Table (2): Serum lipids profile of obese rats.

\begin{tabular}{|l|l|l|l|l|l|l|}
\hline $\begin{array}{l}\text { Groups } \\
\text { Variables }\end{array}$ & $\begin{array}{l}\text { Positive } \\
\text { control }\end{array}$ & $\begin{array}{l}\text { Cabbage } \\
\text { powder }\end{array}$ & $\begin{array}{l}\text { Cabbage } \\
\text { extract }\end{array}$ & chromium & $\begin{array}{l}\text { Cabbage } \\
\text { powder with } \\
\text { chromium }\end{array}$ & $\begin{array}{l}\text { Cabbage } \\
\text { extract with } \\
\text { chromium }\end{array}$ \\
\hline CHO \\
$(\mathrm{mg} / \mathrm{dl})$ & $277.33 \pm$ & $199.33 \pm$ & $188.65 \pm$ & $2.3 .66 \pm$ & $185.60 \pm$ & $178.41 \pm$ \\
& $39.77^{\mathrm{a}}$ & $28.21^{\mathrm{b}}$ & $26.12^{\mathrm{bc}}$ & $30.14^{\mathrm{b}}$ & $24.14^{\mathrm{bc}}$ & $22.11^{\mathrm{c}}$ \\
\hline TG (mg/dl) & $257.40 \pm$ & $188.71 \pm$ & $161.77 \pm$ & $179.81 \pm$ & $160.71 \pm$ & $150.14 \pm$ \\
& $41.11^{\mathrm{a}}$ & $25.61^{\mathrm{b}}$ & $18.14^{\mathrm{bc}}$ & $21.16^{\mathrm{b}}$ & $17.22^{\mathrm{bc}}$ & $15.44^{\mathrm{d}}$ \\
\hline HDLc $(\mathrm{mg} / \mathrm{dl})$ & $28.11 \pm$ & $39.66 \pm$ & $43.11 \pm$ & $38.20 \pm$ & $41.55 \pm$ & $40.77 \pm$ \\
& $2.17^{\mathrm{c}}$ & $4.01^{\mathrm{ab}}$ & $4.20^{\mathrm{a}}$ & $3.81^{\mathrm{b}}$ & $4.17^{\mathrm{a}}$ & $4.13^{\mathrm{a}}$ \\
\hline LDLc $(\mathrm{mg} / \mathrm{dl})$ & $197.74 \pm$ & $121.93 \pm$ & $113.19 \pm$ & $129.50 \pm$ & $111.91 \pm$ & $107.62 \pm$ \\
& $18.19^{\mathrm{a}}$ & $12.11^{\mathrm{b}}$ & $10.33^{\mathrm{c}}$ & $11.71^{\mathrm{b}}$ & $11.33^{\mathrm{c}}$ & $10.15^{\mathrm{c}}$ \\
\hline VLDLc $(\mathrm{mg} / \mathrm{dl})$ & $51.48 \pm$ & $37.74 \pm$ & $32.35 \pm$ & $35.96 \pm$ & $32.14 \pm$ & $3.02 \pm$ \\
& $6.11^{\mathrm{a}}$ & $3.10^{\mathrm{b}}$ & $3.12^{\mathrm{c}}$ & $3.11^{\mathrm{bc}}$ & $3.14^{\mathrm{c}}$ & $3.01^{\text {cd }^{\mathrm{c}}}$ \\
\hline CHO/HDLc & $9.86 \pm$ & $5.02 \pm$ & $4.37 \pm$ & $5.33 \pm$ & $4.46 \pm$ & $4.37 \pm$ \\
& $1.14^{\mathrm{a}}$ & $0.67^{\mathrm{b}}$ & $0.42^{\mathrm{c}}$ & $0.66^{\mathrm{b}}$ & $0.53^{\mathrm{c}}$ & $0.57^{\mathrm{c}}$ \\
\hline
\end{tabular}

Results are expressed as Mean \pm SD

CHO: cholesterol, TG: triglyceride, HDLc: high density lipoprotein cholesterol, LDLc: low density lipoprotein cholesterol, VLDLc: very low density lipoprotein cholesterol , CHO/ HDLc: cholesterol/ high density lipoprotein cholesterol

Mean values in each raw having different superscript were significantly different at $p \leq 0.05$ 
In the present study, it was observed in table (2) that positive control group had the highest values of lipid profiles and CHO/HDLc and lowest value of HDLc among experimental groups as expected. Obese rats administered by cabbage powder or extract alone or in combination with chromium had significantly lower $\mathrm{CHO}$ and TG. Obese rats that administer basal diet with cabbage extract with chromium had the most prominent reduction of $\mathrm{CHO}$ and TG compared with positive control group. All the treated groups under this study showed significant increase HDLc and appeared more elevated in obese rats administered cabbage extract, cabbage powder with chromium and cabbage extract with chromium compared with positive control group. The obtained results showed significant decrease of LDLc, VLDLc and atherogenic index (CHO/HDLc) in all treated groups and appeared obviously in rats groups administered cabbage extract, cabbage powder with chromium and cabbage extract with chromium compared with positive control group.

Results of positive group were explained by previous studies that showed consumption of high fat diet had higher lipids profiles, hypertension, nonalcoholic fatty liver disease and hepatocarcinoma. Abnormally hyperlipidemia can lead to increase athrogenic index and increase various cardiovascular diseases such coronary heart disease and atherosclerosis (Bray et al., 2004 and Panchal et al., 2011). On the other side, administration of glucosinolates in red cabbage (sulfur plant metabolites) and hydrolysis products (isothiocyanate \& sulforaphane) could modify lipid metabolism in vitro and in vivo (Choi et al., 2014 and Miyata et al., 2016). Most of the concerns regarding reductions in serum cholesterol, triglyceride, LDL-c, levels and increases in HDLc have observed in chromium supplementation (Kobla and Volpe 2000). Administration of cabbage either powder or extract with chromium showed the most improvement of lipids profiles because red cabbage extract is rich in anthocyanin that prevents cardiac and hepatic oxidative stress and reduces cardiovascular risks in obese rats. Polyphenol extracts from red cabbage could reduce cholesterol level in hypercholesterolemia. Also, Polyphenols in Brassica vegetable have hypolipidemic, anti-inflammatory and anticancer properties (Sankhari et al., 2012, Cassidy et al., 2013 and Jana et al., 2017). 
Table (3): Liver total lipids, cholesterol and triglyceride of obese rats.

\begin{tabular}{|l|l|l|l|l|l|l|}
\hline $\begin{array}{l}\text { Groups } \\
\text { Variables }\end{array}$ & $\begin{array}{l}\text { Positive } \\
\text { control }\end{array}$ & $\begin{array}{l}\text { Cabbage } \\
\text { powder }\end{array}$ & $\begin{array}{l}\text { Cabbage } \\
\text { extract }\end{array}$ & chromium & $\begin{array}{l}\text { Cabbage } \\
\text { powder } \\
\text { with } \\
\text { chromium }\end{array}$ & $\begin{array}{l}\text { Cabbage } \\
\text { extract } \\
\text { with } \\
\text { chromium }\end{array}$ \\
\hline $\begin{array}{l}\mathrm{TL}(\mathrm{mg} / \mathrm{g} \\
\text { tissue })\end{array}$ & $\begin{array}{l}45.11 \pm \\
3.11^{\mathrm{a}}\end{array}$ & $\begin{array}{l}37.10 \pm \\
2.96^{\mathrm{bc}}\end{array}$ & $\begin{array}{l}35.50 \pm \\
3.11^{\mathrm{cd}}\end{array}$ & $\begin{array}{l}38.03 \pm \\
3.07^{\mathrm{bc}}\end{array}$ & $\begin{array}{l}34.14 \pm \\
3.33^{\mathrm{d}}\end{array}$ & $\begin{array}{l}32.43 \pm \\
2.69^{\mathrm{d}}\end{array}$ \\
\hline $\begin{array}{l}\mathrm{CHO}(\mathrm{mg} / \mathrm{g} \\
\text { tissue) }\end{array}$ & $5.87 \pm$ & $3.71 \pm$ & $3.17 \pm$ & $4.07 \pm$ & $3.22 \pm$ & $3.42 \pm$ \\
\hline $\begin{array}{l}\mathrm{TG}(\mathrm{mg} / \mathrm{g} \\
\text { tissue) }\end{array}$ & $0.77^{\mathrm{a}}$ & $0.41^{\mathrm{c}}$ & $0.43^{\mathrm{c}}$ & $0.36^{\mathrm{b}}$ & $0.25^{\mathrm{c}}$ & $0.33^{\mathrm{c}}$ \\
\hline
\end{tabular}

Results are expressed as Mean \pm SD

TL: total lipids CHO: cholesterol TG: triglyceride

Mean values in each raw having different superscript were significantly different at $p \leq 0.05$

Positive obese group had a significant increase of total lipids (TL) and cholesterol (CHO) and decrease of triglyceride (TG) in liver compared with treated groups. . On the other hand, rat groups that consumed cabbage extract, cabbage powder with chromium and cabbage extract with chromium had the lowest values of liver TL and $\mathrm{CHO}$ and highest value of liver TG compared with positive control group as shown in table( 3 ).

These results were explained by Panchal et al., (2011) who reported that consumption of high fat showed elevated the accumulation of fat in the liver and dysfunction because of leakage of cellular enzymes in the blood. Consumption of cabbage powder or chromium separately could lower liver TL and $\mathrm{CHO}$ but increase in TG Chromium has an important role in proper meatabolic process and normal physiological function as lowering risk of cardiovascular diseases including reduction of total cholesterol, triglycerides, insulin and glucose elevate of HDL-cholesterol (Pittler et al., 2003). Similar results were reported by Hummel et al., (2007), Chen et al., (2009) and Chang et al., 2021).

Most of the concerns regarding the efficacy of red cabbage as antioxidant and prevent liver inflammation as cabbage is super foods rich in vitamin, minerals and antioxidants (Kim et al., 2004). Phenolics in red cabbage are antioxidants that reduce the formation of free radicals so inhibit oxidation of low density lipoproteins and prevent atherosclerosis (Duchnowicz et al., 2012). 
Table (4): Hepatic marker enzymes in serum of the experimental obese rats.

\begin{tabular}{|l|l|l|l|l|l|l|}
\hline $\begin{array}{l}\text { Groups } \\
\text { Variables }\end{array}$ & $\begin{array}{l}\text { Positive } \\
\text { control }\end{array}$ & $\begin{array}{l}\text { Cabbage } \\
\text { powder }\end{array}$ & $\begin{array}{l}\text { Cabbage } \\
\text { extract }\end{array}$ & chromium & $\begin{array}{l}\text { Cabbage } \\
\text { powder with } \\
\text { chromium }\end{array}$ & $\begin{array}{l}\text { Cabbage } \\
\text { extract with } \\
\text { chromium }\end{array}$ \\
\hline ALT $(\mu / \mathrm{l})$ & $39.11 \pm$ & $29.77 \pm$ & $28.24 \pm$ & $31.41 \pm$ & $26.33 \pm$ & $25.17 \pm$ \\
& $3.51^{\mathrm{a}}$ & $2.79^{\mathrm{b}}$ & $3.10^{\mathrm{b}}$ & $3.08^{\mathrm{b}}$ & $2.96^{\mathrm{bc}}$ & $3.11^{\mathrm{c}}$ \\
\hline AST $(\mu / \mathrm{l})$ & $48.75 \pm$ & $38.98 \pm$ & $37.99 \pm$ & $41.14 \pm$ & $35.21 \pm$ & $33.81 \pm$ \\
& $5.69^{\mathrm{a}}$ & $5.11^{\mathrm{b}}$ & $4.14^{\mathrm{b}}$ & $4.99^{\mathrm{b}}$ & $4.07^{\mathrm{bc}}$ & $3.11^{\mathrm{c}}$ \\
\hline ALP $(\mu / \mathrm{l})$ & $80.41 \pm$ & $72.11 \pm$ & $70.44 \pm$ & $73.22 \pm$ & $71.31 \pm$ & $66.14 \pm$ \\
& $9.17^{\mathrm{a}}$ & $8.40^{\mathrm{b}}$ & $7.16^{\mathrm{b}}$ & $7.99^{\mathrm{b}}$ & $8.01^{\mathrm{b}}$ & $6.19^{\mathrm{bc}}$ \\
\hline$\gamma \mathrm{GT}(\mu / \mathrm{ml})$ & $6.33 \pm$ & $4.35 \pm$ & $4.95 \pm$ & $4.90 \pm$ & $4.94 \pm$ & $4.75 \pm$ \\
& $0.55^{\mathrm{a}}$ & $0.41^{\mathrm{bc}}$ & $0.37^{\mathrm{b}}$ & $0.39^{\mathrm{b}}$ & $0.41^{\mathrm{b}}$ & $0.32^{\mathrm{b}}$ \\
\hline $\mathrm{LDH}$ & $250.88 \pm$ & $181.33 \pm$ & $178.55 \pm$ & $190.14 \pm$ & $171.18 \pm$ & $166.57 \pm$ \\
$(\mathrm{U} / \mathrm{L})$ & $34.11^{\mathrm{a}}$ & $19.96^{\mathrm{b}}$ & $17.41^{\mathrm{bc}}$ & $22.10^{\mathrm{b}}$ & $18.55^{\mathrm{bc}}$ & $17.18^{\mathrm{c}}$ \\
\hline
\end{tabular}

Results are expressed as Mean \pm SD

ALT: alanine amino transferase, AST: aspartate amino transferase, ALP: alkaline phosphatase,

$\gamma \mathrm{GT}$ : gamma glutamyl transferase, LDH: lactate dehydrogenase (LDH)

Mean values in each raw having different superscript were significantly different at $p \leq 0.05$

Positive obese group had a significant increase in hepatic markers (ALT, AST, ALP, $\gamma \mathrm{GT}$ and $\mathrm{LDH}$ ) in serum compared with all the treated groups. These markers are functional diagnostic of liver damage due to consumption of high fat diet. Accumulation of lipids in liver cells causes nonalcoholic hepatic steatosies and increase hepatic inflammation (Bechmann et al., 2012). The obtained results in table (4) showed also reduction in levels of these markers (ALT, AST, ALP, $\gamma \mathrm{GT}$ and LDH) in the treated group administration of red cabbage in the form of powder or extract with or without chromium however, no significant difference between the treated s rats groups and most favorable results were found in cabbage extract with chromium group compared with positive control group. Red cabbage contains flavonoids as isothiocyanates, anthocyanins and glutamine amino acid that have antiinflammatory and anticancer (Lee et al., 2018). Previous studies on anthocyanin and Zeaxanthin dipalmitate of red cabbage extract showed prevention hepatic oxidative stress in obese rat consumed high fat diet (Sankhari et al., 2012 and Xiao et al., 2014). 
Table (5): Serum antioxidant enzymes of obese rats.

\begin{tabular}{|l|l|l|l|l|l|l|}
\hline $\begin{array}{l}\text { Groups } \\
\text { Variables }\end{array}$ & $\begin{array}{l}\text { Positive } \\
\text { control }\end{array}$ & $\begin{array}{l}\text { Cabbage } \\
\text { powder }\end{array}$ & $\begin{array}{l}\text { Cabbage } \\
\text { extract }\end{array}$ & chromium & $\begin{array}{l}\text { Cabbage } \\
\text { powder } \\
\text { with } \\
\text { chromium }\end{array}$ & $\begin{array}{l}\text { Cabbage } \\
\text { extract } \\
\text { with } \\
\text { chromium }\end{array}$ \\
\hline $\begin{array}{l}\text { SOD } \\
(\mu / \mathrm{ml})\end{array}$ & $\begin{array}{l}17.55 \pm \\
1.81^{\mathrm{c}}\end{array}$ & $\begin{array}{l}27.33 \pm \\
2.14^{\mathrm{ab}}\end{array}$ & $\begin{array}{l}23.24 \pm \\
3.15\end{array}$ & $\begin{array}{l}25.11 \pm \\
2.33^{\mathrm{b}}\end{array}$ & $\begin{array}{l}30.03 \pm \\
3.10^{\mathrm{a}}\end{array}$ & $\begin{array}{l}30.96 \pm \\
3.24^{\mathrm{a}}\end{array}$ \\
\hline $\mathrm{CAT}$ & $120.20 \pm$ & $190.71 \pm$ & $199.88 \pm$ & $189.41 \pm$ & $217.24 \pm$ & $241.32 \pm$ \\
$(\mu / \mathrm{ml})$ & $10.42^{\mathrm{c}}$ & $20.35^{\mathrm{b}}$ & $20.33^{\mathrm{b}}$ & 19.17 & $25.19^{\mathrm{a}}$ & $22.13^{\mathrm{a}}$ \\
\hline $\mathrm{GST}$ & $55.40 \pm$ & $82.17 \pm$ & $88.33 \pm$ & $80.11 \pm$ & $91.44 \pm$ & $95.11 \pm$ \\
$(\mu / \mathrm{ml})$ & $4.59^{\mathrm{c}}$ & $8.10^{\mathrm{ab}}$ & $7.50^{\mathrm{ab}}$ & $7.81^{\mathrm{ab}}$ & $8.11^{\mathrm{a}}$ & $7.22^{\mathrm{a}}$ \\
\hline $\mathrm{GPX}$ & $26.16 \pm$ & $58.22 \pm$ & $60.33 \pm$ & $55.14 \pm$ & $62.25 \pm$ & $63.11 \pm$ \\
$(\mu / \mathrm{ml})$ & $2.14^{\mathrm{c}}$ & $5.18^{\mathrm{ab}}$ & $5.88^{\mathrm{a}}$ & $4.25^{\mathrm{ab}}$ & $6.07^{\mathrm{a}}$ & $5.11^{\mathrm{a}}$ \\
\hline $\mathrm{MDA}$ & $11.25 \pm$ & $8.75 \pm$ & $7.39 \pm$ & $8.80 \pm$ & $7.44 \pm$ & $7.01 \pm$ \\
$(\mathrm{mmol} / \mathrm{l})$ & $2.10^{\mathrm{a}}$ & $1.35^{\mathrm{b}}$ & $1.17^{\mathrm{bc}}$ & $1.44^{\mathrm{b}}$ & $1.22^{\mathrm{bc}}$ & $1.30^{\mathrm{bc}}$ \\
\hline
\end{tabular}

Results are expressed as Mean $\pm \mathrm{SD}$

SOD: Serum superoxide dismutase, CAT: catalase, GST: glutathione transferase, GPX: glutathione peroxidase, MDA malondialdehyde

Mean values in each raw having different superscript were significantly different at $p \leq 0.05$

The activity of antioxidant enzymes were shown in table (5). Positive obese rat had significantly lower levels of SOD, CAT, GST and GPX and significantly higher of oxidant MDA. However, all treated groups that consumed basal diets with red cabbage as powder or extract with or without chromium had significant increase in SOD, CAT, GST and GPX and significantly lower of MDA compared to positive control group. Furthermore, the best obtained results in improving antioxidant enzymes and reduction of oxidant were appeared obviously in rats groups administered cabbage powder with chromium or cabbage extract with chromium compared with positive control group.

Laboratory and clinical evidence indicated that obesity is related with elevated oxidative stress as hyperlipidemia increase production of reactive oxygen species by NADPH oxidase activation that increases lipid peroxidation (Beltowski et al., 2000, Zhang et al., 2005 and Amirkhizi et al., 2010). Vegetables are rich in natural antioxidants like vitamin $\mathrm{C}$ and $\mathrm{E}$ and phenolic compounds. Red cabbage is rich in kaemferol, isorhamnetin and acylated anthocyanins which have strong antioxidant activity and therapeutic properties (Thakur et al., 2014 and Lee 2017). Red cabbage contains many vitamins (vitamin C, vitamin B5, vitamin B6 and vitamin B1), minerals (potassium, manganese, iron, and magnesium) and phytochemicals which are powerful 
antioxidants (Hassimotto et al., 2005). The obtained results showed significant positive relations between chromium consumption and elevation of antioxidant enzymes and that agreed with results of Sahin et al., (2007).

These results, along with the observed improved lipid and antioxidants with reduction of body weight suggested that red cabbage powder or extract alone or in combination with chromium is beneficial for obesity caused by a high fat diet. The recommendation from this study is administration of red cabbage and chromium in regimen diet for lowering body weight and improving the status of diseases related to obesity. Further studies are needed to determine the mechanisms of action the red cabbage and chromium in the obtained effects.

\section{REFERENCES}

Abo-Allam, R. M. (2003): Data statistical analysis using SPSS program. 1st ed., Publication for Universities, Cairo

Amirkhizi, F., Siassi, F., Minaie, S., Djalali, M., Rahimi, A., \& Chamari, M. (2010). Is obesity associated with increased plasma lipid peroxidation and oxidative stress in women?. Arya Atherosclerosis, 2(4):189-192.

Artham, S. M., Lavie, C. J., Milani, R. V., \& Ventura, H. O. (2008). The obesity paradox: impact of obesity on the prevalence and prognosis of cardiovascular diseases. Postgraduate medicine, 120(2), 34-41.

Baetge , C., Earnest, C. P., Lockard, B., Coletta, A. M., Galvan, E., Rasmussen, C., \& Oliver, J. (2017). Efficacy of a randomized trial examining commercial weight loss programs and exercise on metabolic syndrome in overweight and obese women. Applied Physiology, Nutrition, and Metabolism, 42(2), 216-227.

Bechmann, L. P., Hannivoort, R. A., Gerken, G., Hotamisligil, G. S., Trauner, M., \& Canbay, A. (2012). The interaction of hepatic lipid and glucose metabolism in liver diseases. Journal of hepatology, 56(4), 952964.

Beltowski, J., Wojcicka, G., Gorny, D., \& Marciniak, A. (2000). The effect of dietary-induced obesity on lipid peroxidation, antioxidant enzymes and total plasma antioxidant capacity. Journal of Physiology and Pharmacology, 51(4, 2) :883-896. 
Bray, G. A., Paeratakul, S., \& Popkin, B. M. (2004). Dietary fat and obesity: a review of animal, clinical and epidemiological studies. Physiology \& behavior, 83(4), 549-555.

Cassidy, A., Mukamal, K. J., Liu, L., Franz, M., Eliassen, A. H., \& Rimm, E. B. (2013). High anthocyanin intake is associated with a reduced risk of myocardial infarction in young and middle-aged women. Circulation, 127(2), 188-196.

Chang, G. R., Hou, P. H., Yang, W. C., Wang, C. M., Fan, P. S., Liao, H. J., \& Chen, T. P. (2021). Doxepin exacerbates renal damage, glucose intolerance, nonalcoholic fatty liver disease and urinary chromium loss in obese mice. Pharmaceuticals, 14(3), 267.

Chen, W. Y., Chen, C. J., Liu, C. H., \& Mao, F. C. (2009). Chromium supplementation enhances insulin signalling in skeletal muscle of obese KK/HIJ diabetic mice. Diabetes, Obesity and Metabolism, 11(4), 293303.

Choi, K. M., Lee, Y. S., Kim, W., Kim, S. J., Shin, K. O., Yu, J. Y., \& Yoo, H. S. (2014). Sulforaphane attenuates obesity by inhibiting adipogenesis and activating the AMPK pathway in obese mice. The Journal of nutritional biochemistry, 25(2), 201-207.

Claiborne, A. (1985). Handbook of methods for oxygen radical research. Florida: CRC Press, Boca Raton.

Cohn, J. S., McNamara, J. R., \& Schaefer, E. J. (1988). Lipoprotein cholesterol concentrations in the plasma of human subjects as measured in the fed and fasted states. Clinical chemistry, 34(12), 2456-2459.

Draghici, G. A., Lupu, M. A., Borozan, A. B., Nica, D., Alda, S., Alda, L., \& Bordean, D. M. (2013). Red cabbage, millennium's functional food. Journal of Horticulture, Forestry, and Biotechnology, 17(4), 52-55.

Duchnowicz, P., Bors, M., Podsędek, A., Koter-Michalak, M., \& Broncel, M. (2012). Effect of polyphenols extracts from Brassica vegetables on erythrocyte membranes (in vitro study). Environmental toxicology and pharmacology, 34(3), 783-790.

Ellman, M. (1959). A spectrophotometric method for determination of reduced glutathione in tissues. Anal Biochem, 74, 214-226.

Folch, J., Lees, M., \& Stanley, G. S. (1957). A simple method for the isolation and purification of total lipides from animal tissues. Journal of biological chemistry, 226(1), 497-509. 
Foster, L. B., \& Dumns, T. T. (1973). Determination of triglycerides. J. Clin. Chem, 19, 338-353.

Fried, M., Hainer, V., Basdevant, A., Buchwald, H., Deitel, M., Finer, N. \& Steffen, R. (2008). Interdisciplinary European guidelines on surgery of severe obesity. Obesity facts, 1(1), 52-59.

Friedewald, W.T., Levy, R.I.\&Fredrickson, D.S. (1972): Estimation of the concentration of low-density lipoprotein cholesterol in plasma, without use of the preparative ultracentrifuge. Clin Chem;18:499-502.

Hassimotto, N. M. A., Genovese, M. I., \& Lajolo, F. M. (2005). Antioxidant activity of dietary fruits, vegetables, and commercial frozen fruit pulps. Journal of Agricultural and Food Chemistry, 53(8), 2928-2935.

Henagan, T. M., Cefalu, W. T., Ribnicky, D. M., Noland, R. C., Dunville, K., Campbell, W. W. \& Morrison, C. D. (2015). In vivo effects of dietary quercetin and quercetin-rich red onion extract on skeletal muscle mitochondria, metabolism, and insulin sensitivity. Genes \& nutrition, 10(1), 2-12.

Hummel, M., Standl, E., \& Schnell, O. (2007). Chromium in metabolic and cardiovascular disease. Hormone and metabolic research, 39(10), 743751.

Im, K. H., Choi, J., Baek, S. A., \& Lee, T. S. (2018). Hyperlipidemic inhibitory effects of Phellinus pini in rats fed with a high fat and cholesterol diet. Mycobiology, 46(2), 159-167.

Jain, S. K., Croad, J. L., Velusamy, T., Rains, J. L., \& Bull, R. (2010). Chromium dinicocysteinate supplementation can lower blood glucose, CRP, MCP-1, ICAM-1, creatinine, apparently mediated by elevated blood vitamin $\mathrm{C}$ and adiponectin and inhibition of $\mathrm{NF \kappa B}$, Akt, and Glut-2 in livers of zucker diabetic fatty rats. Molecular nutrition \& food research, 54(9), 1371-1380.

Jain, S. K., Rains, J. L., \& Croad, J. L. (2007). Effect of chromium niacinate and chromium picolinate supplementation on lipid peroxidation, TNF- $\alpha$, IL-6, CRP, glycated hemoglobin, triglycerides, and cholesterol levels in blood of streptozotocin-treated diabetic rats. Free Radical Biology and Medicine, 43(8), 1124-1131.

Jana, S., Patel, D., Patel, S., Upadhyay, K., Thadani, J., Mandal, R., \& Devkar, R. (2017). Anthocyanin rich extract of Brassica oleracea L. alleviates experimentally induced myocardial infarction. PloS one, 12(8):0182137. 
Jovanovski, E., Mazhar, N., Komishon, A., Khayyat, R., Li, D., Mejia, S. B., \& Vuksan, V. (2020). Effect of viscous fiber supplementation on obesity indicators in individuals consuming calorie-restricted diets: a systematic review and meta-analysis of randomized controlled trials. European journal of nutrition, 1-12.

Kim, D. O., Padilla-Zakour, O. I., \& Griffiths, P. D. (2004). Flavonoids and antioxidant capacity of various cabbage genotypes at juvenile stage. Journal of Food Science, 69(9), C685-C689.

Kim, S. J., Choi, Y., Jun, H. S., Kim, B. M., Na, H. K., Surh, Y. J., \& Park, T. (2010). High-fat diet stimulates IL-1 type I receptor-mediated inflammatory signaling in the skeletal muscle of mice. Molecular nutrition \& food research, 54(7), 1014-1020.

Kobla, H. V., \& Volpe, S. L. (2000). Chromium, exercise, and body composition. Critical reviews in food science and nutrition, 40(4), 291308 .

Lee, H., Seo, H. S., Kim, R. E., Lee, S. K., Lee, Y. H., \& Shin, C. (2021).

Obesity and muscle may have synergic effect more than independent effects on brain volume in community-based elderly. European Radiology, 31(5), 2956-2966.

Lee, J. (2017). Physicochemical characteristics and antioxidant effects of red mustard (Brassica juncea L.) leaf using different drying methods. The Korean Journal of Community Living Science, 28(4), 515-524.

Lee, J. J., Kim, H. A., \& Lee, J. (2018). The effects of Brassica juncea L. leaf extract on obesity and lipid profiles of rats fed a high-fat/high-cholesterol diet. Nutrition research and practice, 12(4), 298-306.

Leja, M., Kamińska, I., \& Kolton, A. (2010). Phenolic compounds as the major antioxidants in red cabbage. Folia Horticulturae, 22(1), 19-24.

Majkowska-Gadomska, J., \& Wierzbicka, B. (2008). Content of basic nutrients and minerals in heads of selected varieties of red cabbage (Brasicca oleracea var. capitata f. rubra). Polish Journal of Environmental Studies, 17(2), 295-298.

Michalakis, K., Mintziori, G., Kaprara, A., Tarlatzis, B. C., \& Goulis, D. G. (2013). The complex interaction between obesity, metabolic syndrome and reproductive axis: a narrative review. Metabolism, 62(4), 457-478. 
Miyata, S., Inoue, J., Shimizu, M., \& Sato, R. (2016). Allyl isothiocyanate suppresses the proteolytic activation of sterol regulatory element-binding proteins and de novo fatty acid and cholesterol synthesis. Bioscience, biotechnology, and biochemistry, 80(5), 1006-1011.

Molz, P., Molz, W. A., Dallemole, D. R., Weber, A. F., Salvador, M., Prá, D., \& Franke, S. I. (2021). Potential ameliorative effects of chromium supplementation on glucose metabolism, obesity, and genomic stability in prediabetic rat model. Biological Trace Element Research, 199(5), 18931899.

Nandi, A., \& Chatterjee, I. B. (1988). Assay of superoxide dismutase activity in animal tissues. Journal of Biosciences, 13(3), 305-315.

Navaro, D. A., Raz, O., Gabriel, S., Shriqui, V. K., Gonen, E., \& Boaz, M. (2017). Functional Foods in fad diets: A review. Functional Foods in Health and Disease, 7(9), 702-715.

Necheles, T. F., Steinberg, M. H., \& Cameron, D. (1970). Erythrocyte glutathione-peroxidase deficiency. British journal of haematology, 19(5), 605-612.

Panchal, S. K., Poudyal, H., Iyer, A., Nazer, R., Alam, A., Diwan, V. \& Gobe, G. (2011). High-carbohydrate, high-fat diet-induced metabolic syndrome and cardiovascular remodeling in rats. Journal of cardiovascular pharmacology, 57(5), 611-624.

Pittler, M. H., Stevinson, C., \& Ernst, E. (2003). Chromium picolinate for reducing body weight: meta-analysis of randomized trials. International journal of obesity, 27(4), 522-529.

Podsę-dek, A., Sosnowska, D., Redzynia, M., \& Anders, B. (2006). Antioxidant capacity and content of Brassica oleracea dietary antioxidants. International journal of food science \& technology, 41, 4958 .

Reeves, P.G, Nielsen FH. \&Fahey GC (1993). AIN-93 purified diets for laboratory rodents: final report of the American Institute of Nutrition ad hoc writing committee on the reformulation of the AIN-76A rodent diet. $J$ Nutr, 123, 1939-1951.

Rosenfeld, L. (1989). Lipoprotein analysis. Early methods in the diagnosis of atherosclerosis. Archives of pathology \& laboratory medicine, 113(10), 1101-1110. 
Sahin, K., Onderci, M., Tuzcu, M., Ustundag, B., Cikim, G., Ozercan, İ. H., \& Komorowski, J. R. (2007). Effect of chromium on carbohydrate and lipid metabolism in a rat model of type 2 diabetes mellitus: the fat-fed, streptozotocin-treated rat. Metabolism, 56(9), 1233-1240.

Sankhari, J. M., Thounaojam, M. C., Jadeja, R. N., Devkar, R. V., \& Ramachandran, A. V. (2012). Anthocyanin-rich red cabbage (Brassica oleracea L.) extract attenuates cardiac and hepatic oxidative stress in rats fed an atherogenic diet. Journal of the Science of Food and Agriculture, 92(8), 1688-1693.

Thakur, A. K., Chatterjee, S. S., \& Kumar, V. (2014). Antidepressant-like effects of Brassica juncea L. leaves in diabetic rodents. Indian Journal of experimental biology, 52(06),613-622.

Tietz, N.W. (1976). Fundamental of Clinical Chemistry. Philadelphia, W.B. Saunders,P. 243.

Uchiyama, M. and M. Mihara, (1978). Determination of malondialdhyde precursor in tissues by thiobarbituric acid test. Anal. Biochem., 86(1): 271-278.

Vincent, J. B. (2006). Chromium: biological relevance. Encyclopedia of inorganic chemistry. John Wiley \& Sons, Ltd.

Wease, D. F., Espinosa, E. S., \& Anderson, Y. J. (1975). New system for automated extraction and simultaneous determination of serum cholesterol and triglycerides. Clinical chemistry, 21(10), 1430-1436.

Xiao, J., Wang, J., Xing, F., Han, T., Jiao, R., Liong, E. C.\& Tipoe, G. L. (2014). Zeaxanthin dipalmitate therapeutically improves hepatic functions in an alcoholic fatty liver disease model through modulating MAPK pathway. PloS one, 9(4): e95214.

Zhang, Q. W., Lin, L. G., \& Ye, W. C. (2018). Techniques for extraction and isolation of natural products: A comprehensive review. Chinese medicine, 13(1), 1-26.

Zhang, X., Dong, F., Ren, J., Driscoll, M. J., \& Culver, B. (2005). High dietary fat induces NADPH oxidase-associated oxidative stress and inflammation in rat cerebral cortex. Experimental neurology, 191(2), 318325.

Zlatkis, A., \& Zak, B. (1969). Study of a new cholesterol reagent. Analytical biochemistry, 29(1), 143-148. 


\section{ملخص البحث}

\section{التاثيرات التأزرية المضادة للسمنة لتناول الكرنب الأحمر والكروم على الفئران البدينة}

أجريت هذه الدراسة لتقييم التاثير التأزري لأوراق الكرنب الاحمر علي صورة مسحوق أو مستخلص ميثانولي مع وبدون الكروم علي الفئران المصابة بالسمنة عن طريق تقييم المؤشرات الغذائية و دهون السيرم والإنزيمات المضادة للأكسدة و بعض وظائف الكبد. وتم إصابة الفئران بالسمنة عن طريق تغذيتها علي وجبات عالية الدهون لمدة سنة أسابيع. تم تقسيم الفئران المصابة بالسمنة بشكل عشوائي إلى ست مجموعات "سبعة فئران في كل مجموعة" وهي المجموعة الضابطة الإيجابية المصابة بالسمنة والتي تتاولت الوجبة الاساسية والمجموعة المعالجة بمسحوق الكرنب 10 ٪ من مسحوق الكرنب في الوجبة الأساسية والمجموعة المعالجة بالكروم مع الوجبة الاساسية بجرعة ه.ء ميكروجرام/كجم من وزن

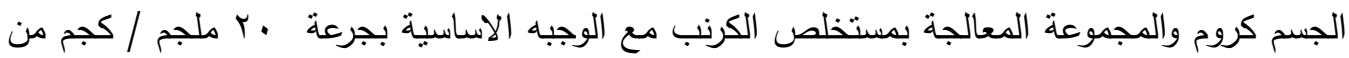
وزن الجسم مستخلص الكرنب والمجموعة المعالجة بمسحوق الكرنب مع الكروم 0 \% من مسحوق الكرنب و ه.ء ميكروجرام/ كجم كروم والمجموعة المعالجة بمستخلص الكرنب مع الكروم مع الوجبه الاساسية • • ملجم /كجم من وزن الجسم لمستخلص الكرنب وه.؛ ميكروجرام/كجم من الكروم. واستمرت الدراسة لمدة · 7 يوما بعد الاصابة بالسمنة. اسفرت نتائج الدراسة علي أن نتاول مسحوق الكرنب مع الكروم أومستخلص الكرنب مع الكروم اظهر نقص معنوي في الوزن المكتسب والمتتاول من الطعام ونسبه كفاءه الطعام بالمقارنة بالمجموعة الضابطه الإيجابية المريضة بالسمنة. كما أظهرت جميع المجموعات المعالجة تحسن معنوي في كل من مؤشرات الدهون في السيرم والكبد وتحسن معنوي في انزيمات كفاءه الكبد ومضادات الاكسده وكانت افضل النتائج في المجموعات المتناولة لمسحوق الكرنب مع الكروم و المتتاوله لمستخلص الكرنب مع الكروم بالمقارنة مع المجموعة الضابطه الإيجابية. وتوصي نتائج الدراسة بضرورة تتاول الكرنب الاحمرومستخلصه مع الكروم كنظام غذائي لمرضي السمنة لما له من ناثيرات ايجابية علي نقص الوزن وتحسين وظائف الكبد وخفض دهون الدم.

الكلمات المفتاحية : الكرنب الاحمر - الكروم - السمنة - الفئران - دهون الدم- مضادات الاكسدة 